\title{
TÉCNICA HIDRÁULICA Y REGADÍO EN EL BAJO SEGURA: LA CONSTRUCCION DEL AZUD DE ALFAYTAMÍ Y LAS REMODELACIONES EN LA RED DE IRRIGACIÓN (1571-1598)*
}

\author{
DAVID BERNABÉ GIL
}

Universidad de Alicante

Fecha de recepción: diciembre de 2010

Fecha de aceptación: febrero de 2011

\section{INTRODUCCIÓN}

Las construcciones hidráulicas experimentaron en tiempos de Felipe II un desarrollo sin precedentes, que tuvo ocasión de manifestarse de un modo especialmente visible en la expansión y mejora de los regadíos operada en toda la cuenca mediterránea. Estimuladas por la favorable coyuntura expansiva que afectó a la economía agraria durante buena parte de este periodo, las iniciativas surgidas en la realización de presas y embalses y en la racionalización de los sistemas de irrigación contribuyeron a intensificar las formas de aprovechamiento de ese bien escaso, con alto potencial productivo, que eran las aguas discurrientes por todo tipo de cauces naturales. Sin necesaria dependencia de la administración real, aun escasamente involucrada en las labores de fomento del territorio constitutivo del real patrimonio, fueron múltiples las realizaciones hidráulicas emprendidas por diversas instancias institucionales para ampliar y mejorar los rendimientos obtenidos de las explotaciones agrarias y, con ello, conseguir la adaptación a las nuevas exigencias, derivadas de una demanda de bienes alimenticios e industriales en constante crecimiento. La tendencia alcista dibujada por

\footnotetext{
* Este trabajo ha sido realizado en el marco del Proyecto de Investigación HUM2007-63505, financiado por el Ministerio de Educación y Ciencia.
} 
los precios de los productos agrarios contribuía, además, a alentar las perspectivas de rentabilización de las inversiones realizadas en este tipo de infraestructuras ${ }^{1}$.

Estimulada por las posibilidades abiertas en este ámbito, la tecnología en materia hidráulica se vio impelida a ofrecer adecuada respuesta a los nuevos retos planteados, mediante una serie de soluciones constructivas que, en general, coadyuvaron de forma decisiva al avance de esta rama de la ingeniería. La existencia ya a lo largo del Quinientos de destacados ingenieros con profundos conocimientos en la fabricación de presas y en la conducción de aguas contribuyó seguramente a difundir algunas técnicas que permitieron llevar a cabo una multitud de modestas realizaciones -cuyo inventario todavía resultaría prematuro-, en consonancia con la coyuntura expansiva que afectó al sector agrario de la cuenca mediterránea Mas no siempre fueron prestigiosas o reconocidas personalidades, portadoras de conocimientos avanzados en la materia, las llamadas a dejar su impronta en la variedad de obras acometidas. También una técnica hidráulica de matriz popular, que otorgaba a la tradición y a la experiencia acumulada un protagonismo decisivo en su proceso de conformación, manejada con desigual pericia por maestros canteros, pero también por niveladores y agrimensores, estuvo en la base de un buen número de realizaciones menores que se fueron agregando y que, en conjunto, supusieron una importante renovación de los regadíos tradicionales, de gran arraigo - entre otras razones, por sus condicionantes climáticos- en el levante peninsular.

Pero para una más adecuada comprensión de la dinámica experimentada por los regadíos históricos conviene tomar también en consideración la incidencia de otros elementos estrechamente vinculados a los intereses en juego de los diversos agentes y grupos sociales más directamente implicados o afectados, en las diversas coyunturas. El estudio de los procesos de toma de decisiones y de su plasmación concreta en esta materia quizás permita arrojar alguna luz sobre las estrategias de aquéllos. Las supuestamente diversas posibilidades y capacidades de los diferentes agentes sociales para reconducir en una determinada dirección las transformaciones hidráulicas que se estaban impulsando se erigen, así, en cuestiones que no conviene soslayar; como tampoco deberíamos dejar de atender a las secuelas o consecuencias que se siguieron. Desde este planteamiento, y dejando para otra ocasión el seguimiento de algunas de

\footnotetext{
1. De la extensa bibliografía referente a las transformaciones hidráulicas en este período, vid. los compendios contenidos en Alberola RomÀ, Armando (ed.): Cuatro siglos de técnica hidráulica en tierras alicantinas, Instituto de Estudios Juan Gil-Albert, Alicante, 1995, llevados a cabo por LóPEZ GóMEZ, Antonio: «Las presas españolas del siglo XVI. Antecedentes e innovaciones revolucionarias», pp. 89-116; GONZÁlez TASCÓN, Ignacio: «Ciencia y técnica hidráulicas en la España del Quinientos», pp. 117-140; y BERnABÉ GIL, David: «Política hidráulica en la España de los Austrias», pp. 67-88; donde se contienen referencias a múltiples estudios puntuales. Asímismo, para el levante peninsular, ROMERO, Joan y PERIS, Tomás: «Usos, distribució i control de l'aigua», en Enciclopedia catalana. Els rius y la vegetació, Barcelona, 1992, pp. 186-278: ARDIT LuCAS, Manuel: Els homes i la terra del Pais Valencià (segles XVIXVIII), Curial, Barcelona, 1993, vol. II, pp. 9-35; LEMEUNIER, Guy: «Hidráulica agrícola en la España mediterránea, S. XVI-XVIII. La formación de los espacios clásicos», en BARCIELA LóPEZ, Carlos y Melgarejo Moreno, Joaquín (EDS): El agua en la historia de España, Alicante, 2000, pp. 47-110.
} 
sus repercusiones a medio y largo plazo, me centraré a continuación en la remodelación acometida en la zona de riegos del azud de Alfaytamí durante el último cuarto del Quinientos, para tratar de dilucidar el modo en que se llevó a cabo; y con la esperanza de contribuir a despejar algunas de las claves que permitan comprender mejor su inserción en las coordenadas históricas en que se enmarca.

\section{LA CONSTRUCCIÓN DEL AZUD}

La construcción, en cantería y mampostería, de la presa de derivación conocida como azud de Alfaytamí - o Alfeitamí- va asociada a una profunda remodelación de la red hidráulica a través de la cual se irrigaba un amplio perímetro de huerta comprensivo de los actuales términos municipales de Almoradí, Daya Nueva, Formentera y Benijófar -correspondientes a los antiguos de Almoradí, Daya Nueva y una parte de Guardamar- en el tramo inferior del río Segura, en el sur del antiguo reino de Valencia ${ }^{2}$. Ambos tipos de proyectos, aunque en algún momento quizás llegaran a plantearse de forma conjunta, abarcaron en la práctica una serie de actuaciones que, sin embargo, no se desarrollaron necesariamente de modo simultáneo. A efectos de análisis parece conveniente, pues, un tratamiento diferenciado.

La fábrica del azud tiene, al parecer, un doble precedente. Por un lado, se ha vinculado tradicionalmente a la existencia de una empalizada de piedras, madera y tierra levantada en el cauce del río para dar servicio a un molino harinero, denominado de Alfeitamí, por ubicarse en el paraje del mismo nombre ${ }^{3}$. No obstante, según aseguraba uno de los máximos responsables de su construcción definitiva -el Dr. Luis Ocaña ${ }^{4}$ - solo un par de años después de su culminación, también existió anteriormente otra presa cercana, aguas arriba, levantada provisionalmente con finalidad estrictamente de irrigación. Y habría sido precisamente la rotura de este precario azud, de donde se nutría un pequeño acueducto denominado por los coetáneos Cèquia de $D^{a}$ Ana Rocafull, el detonante que condujo a un amplio grupo de regantes interesados a plantear la conveniencia de acometer la fábrica de una obra de mayor envergadura.

2. Almoradí y Guardamar eran poblaciones de realengo; Daya Nueva, señorío de jurisdicción baronal; Formentera y Benijófar, dos grandes heredades ubicadas en el término de Guardamar, que serían objeto de colonización alfonsina a finales del siglo XVII.

3. Roca de Togores, José: Memoria sobre los riegos de la huerta de Orihuela, Valencia, Benito Monfort, 1832, p. 47; CAnales Martínez, Gregorio y MuÑoz Hernández, Remedios: «El Azud de Alfeitamí (XVI) y la reducción del almarjal en el tramo sur del río Segura (Almoradí)», Congreso Nacional Gestión del agua en cuencas deficitarias, Murcia, Centro de Investigación del Bajo Segura «Alquibla», 2005, p. 86.

4. El Dr. Luis Ocaña, reputado jurista que dio a la imprenta, en 1611, un tratado sobre los derechos del Real Patrimonio en la Baylía General de Orihuela y Alicante, fue asesor de dicha institución y, posteriormente, visitador real de las rentas y oficiales de la ciudad de Orihuela. Ofrecí una breve semblanza del personaje en la «Introducción» a la edición facsímil de su obra: OCAÑA, Lluis de: Llibre de capitols ab los quals se arrenden y collecten els drets que té Sa Magestat en la Batlia General de Oriola i Alacant ab les declaración de com se executen y practiquen, Oriola, 1611, (ed. facsímil, Universidad de Alicante, Alicante, 1999), pp. 7-19. 
Así lo exponía en 1600 el Dr. Ocaña, para que varios testigos lo corroborasen con sus declaraciones:

«los vehins e habitadors de Almoradi y Don Francisco Boil y de Masquefa, señor de la baronia de la Daya, per la necessitat y penuria de aygua que dits llochs patien, axi per a son beure com per a regar ses terres, per haverse romput y trencat lo açut qu.estaria construhit y fet a la part damunt del açut y moli de Alfaytami, en front de la boquera de la Cèquia que huy es y d'ella reguen Don Anna de Rocafull, Serafina Gallicant, Diego LLiminyana y Hieronima Sansa, en lo any mil cinch cents setanta y tres, consellarment delliberaren fer y construir un açut en lo lloch on Francés Gallicant, señor del moli de Alfaytamí, tenia feta una rafa o açut de pedra, atocha y estaques per dit son moli, per a del regolf de dit açut fahedor pendre aygua per a regar ses terres.» ${ }^{5}$.

Pero la idea de aprovechar la endeble infraestructura hidráulica representada por la presa que abastecía al molino para su transformación en un azud permanente de cantería había quedado ya claramente expresada dos años atrás, en el otorgamiento de poderes realizado por la comunidad de regantes de Almoradí y Daya Nueva, en 15 de julio de 1571, a favor del síndico Luis Carbonell, para que, en nombre de aquéllos, acordara con determinadas personalidades las condiciones en que habría de realizarse la fábrica, la remodelación del molino y la apertura de la boquera por donde habría de tomar agua la denominada Cèquia de Almoradí e la Daya. El acuerdo previsto debía incluir al propietario del molino, Francesç Gallicant, y al señor jurisdiccional de la baronía de la Daya, Francisco Boil y Masquefa, como principales interesados; pero también a los propietarios de terrenos previsiblemente afectados por las obras de canalización a emprender: Francesç Martí, Bertomeu Cascant y Jaume Cascant, a los cuales habría que indemnizar por las tahúllas que les fueran tomadas. Un total de 75 propietarios, que constituían algo más de la mitad de los integrantes de la comunidad de hereters, respaldaron entonces con su presencia el protocolo que habría de suscribirse, efectivamente, mes y medio más tarde por el dueño del molino, el señor de la Daya y el síndico de los regantes, donde quedaron ya establecidas las condiciones generales para la construcción del azud y su exacta ubicación ${ }^{6}$.

En relación con la determinación conciliar de 15 de julio, se echa en falta en dicho convenio de 30 de agosto, además, cualquier alusión a los tres dueños de tierras mencionados, al tiempo que apenas se aborda la cuestión de las boqueras y obra nueva de la toma de las acequias ${ }^{7}$. Dejando para más adelante el enigmático asunto de las nuevas acequias, el acuerdo se centraba en tres aspectos fundamentales: la entrega gratuita, por parte del propietario del molino, de los terrenos necesarios y de la piedra existente en la vieja presa; la financiación de las obras con cargo exclusivo a los regantes de Almoradí

5. Archivo del Reino de Valencia (en adelante ARV): Real Audiencia. Procesos $1^{a}$ parte, S/1.748, f. 97v.

6. El texto del sindicat y otorgamiento de poderes por la comunidad de regantes, de 15-07-1571, en Ibidem, ff. $153 \mathrm{v}-156$.

7. El texto de la concordía, de 30-08-1571, mencionada por Roca de Togores, ha sido resumido recientemente por Gregorio Canales y Remedios Muñoz, en «El Azud....», op. cit., pp. 86-87, donde podrá obtenerse mayores detalles. 
y la Daya, por mitad, con exención del propietario del molino; y la introducción de algunas modificaciones en la fábrica del molino y en su abastecimiento del agua, tendentes a asegurar su suministro y reforzar su estructura, sin perjuicio de los nuevos caudales que habrían de recibir los regantes aguas arriba, a través de boqueras abiertas al mismo nivel. Establecidas, a grandes rasgos, las bases sobre las que habría de procederse a la iniciación de la empresa, ésta no comenzaría a concretarse, sin embargo, hasta año y medio más tarde.

El 10 de febrero de 1573 pactaron los aspectos técnicos y económicos de la obra a realizar el ya mencionado Luis Carbonell, como síndico de los regantes, y el procurador del señor de la Daya, Antoni Tonono, con los canteros de Orihuela, maestro Ferrando Velis y Joan Rois ${ }^{8}$. Se indicaba en los 17 capítulos de que constaba el documento que el grosor del azud sería de 25 palmos, desde la reforzada pared del molino -en la margen izquierda- hasta la mota del cauce en la margen derecha -la part del monte-, donde debía penetrar con anchura de 20 palmos. La altura debía tener un palmo más que la pared del trestallador o compuerta ubicada en la margen derecha, aunque no se precisaba sus medidas. El material empleado consistiría en sillares de piedra bien labrados «a cap de martell» en la cara del azud, y en «ripio bo y gran» en la parte trasera. Para abastecer el molino se harían tres canales con sus respectivas boqueras, enlosadas y cubiertas, de 6 palmos de altura cada una. Los constructores aprovecharían de forma gratuita la piedra y demás materiales existentes actualmente y aportarían los pertrechos necesarios a sus expensas, quedando obligados los regantes a obtener licencia de las autoridades municipales de Orihuela -en cuya jurisdicción se insertaba el lugar de Almoradí- para cortar 200 ó 300 estacas de pino en el entorno. El azud quedaba asegurado por dos años, quedando obligados los constructores a rehacerlo o repararlo a su costa en caso de que una avenida del río ocasionara daños en ese intervalo. Pero el corto plazo estipulado para la entrega de la obra acabada -el 30 de septiembre de ese mismo año-y el escaso precio en que se remató su ejecución -solo 2.500 libras-, indicadores de la relativa modestia del proyecto, auguraban una vida no demasiado larga; como, efectivamente, así habría de ocurrir.

En primer lugar, no fueron los mencionados maestros pedrapiquers oriolanos quienes se hicieron finalmente cargo de la obra, sino dos maestros canters llegados de Murcia, apellidados Aguirre - participante, años más tarde, en la construcción del pantano de Almansa, antes de marchar a Cuenca9- y Rueda, al rebajar en 100 libras el precio de remate. Mas aun no habían acabado éstos su ejecución, cuando una posible imprudencia constructiva, no ajena a unas quizás desmedidas aspiraciones lucrativas, dio al traste con el cuerpo del azud, cuando estaba a punto ya de culminarse. Según declaración de un experto, la causa del desastre fue un portillo que dejaron abierto por la parte del monte para que sirviese de trestallador hasta que fuera debidamente enlozado, de modo que en su lecho se fue formando una hondonada o ribazo, hasta que se

8. El contrato de construcción, en ARV: Real Audiencia. Procesos $1^{a}$ parte, S/1.748, ff. 156v-160.

9. Pereda Hernández, M.J.: La construcción de la presa del pantano de Almansa, Almansa, 1986, p. 9. 
desmoronó una pared, por donde rompió el río durante una crecida. Viendo las pérdidas ocasionadas y el enorme esfuerzo y desembolso que representaría su reparación, los canteros murcianos huyeron y dejaron desamparada la obra, obligando a los regantes a cargarse dos censales para llevar a cabo un arreglo de urgencia, que solo aguantó un par de años más, hasta que una nueva avenida del Segura se llevó consigo las ilusiones puestas en los benéficos efectos del azud ${ }^{10}$.

Durante las dos décadas siguientes la situación fue bastante similar a la que se había venido viviendo tradicionalmente. Casi todos los años, aprovechando el estiaje, los regantes levantaban «rafes... de atocha, terra y rama»; pero esta práctica ocasionaba muchos gastos y esfuerzos efímeros, mientras continuaban aumentando las necesidades hídricas «per a regar ses terres y per a servisi y abreurar son bestiar de llauro y ganados, la qual necessitat causava el haverse romput el açut de Alfaytami y no poder fer repressa ni regolf per a que dita Cèquia de Almoradi y Daya pogués pendre aygua». Fue para hacer frente, de una vez por todas, a esta situación de penuria que, en sesión celebrada el 27 de marzo de 1595, el consejo de regantes acordara-bajo la presidencia del justicia civil y criminal de la universidad de Almoradí, en lugar del sobrecequiero«que fora fet y construhit de nou lo dit açut de Alfaytami en lo lloch a hon los pareixerà per a mes convenient als elets que per dit consell seran nomenats». Presentadas dos candidaturas integradas por tres regantes cada una, correspondientes a las dos comunas - de dalt y de baix - en que se dividía la ya denominada Cèquia Mayor de Almoradi y Daya, resultó ganadora esta última por mayoría de votos; y, a continuación, se fijaron las remuneraciones de los electos ${ }^{11}$.

Mas fueron transcurriendo los meses estivales, propicios para comenzar las obras, avanzaba el otoño sin que se observara movimiento alguno y, el 15 de octubre, vuelve a reunirse el consell de regantes para revocar a los electos nombrados, cuya inoperancia estaba dilatando la toma de decisiones. A instancias del síndico de la comuna cuya candidatura había resultado perdedora meses atrás, son elegidos nuevos representantes: el Dr. Luis Ocaña y Joan Sans, quienes, ahora sí, se toman en serio los poderes recibidos para empezar a cargarse censales con que financiar el proyecto y concertar los servicios de los constructores y proveedores de los materiales necesarios. La fatídica experiencia vivida años atrás en relación con la forma de contratación de las obras no habría de quedar en el olvido ${ }^{12}$.

El 10 de diciembre se formalizaba un primer contacto con los pedrapiquers de Almoradí, maestro Cosme Macià y Gines Xátiva, quienes realizaron un informe sobre el terreno acerca del lugar propicio para levantar el azud, el modo de llevar a cabo la empresa y un largo listado de los materiales y pertrechos necesarios. Estimaban que debía construirse donde había estado el viejo, iniciándose por la parte del monte en

10. ARV: Real Audiencia. Procesos $1^{a}$ parte, S/1.748, ff. 108v, 115v-116v; 125v-126; según testimonios aportados por regantes y albañiles que participaron en la construcción.

11. Ibídem, ff. 162-168v; Archivo Histórico Nacional (en adelante AHN): Consejos; leg. 21.930, ff. 113-123; Archivo Histórico de Orihuela (en adelante AHO): Sec. Colegio, L-224, ff. 41v-45.

12. ARV: Real Audiencia. Procesos $1^{a}$ parte, S/1.748, f. 169-172, AHN: Consejos; leg. 21.930, ff. 128-141. 
dirección al molino, de piedra picada en la cara, y piedra ripio menuda con mortero, en medio ${ }^{13}$. Aconsejaban también, a instancias de los electos, la conveniencia de no contratar su ejecución a un tanto alzado o a estall, sino pagando los jornales y materiales realmente empleados. Y tras haberles adjudicado la realización de la obra, a los pocos días comenzaba a subastarse, por separado, el aprovisionamiento de la piedra de cantería, la cal, la arena y la mampostería o ripio. Antes de finalizar el año, ya se había rematado la extracción y transporte de los materiales siguientes -entre otros-, con indicación de las fechas de entrega, lugares de aprovisionamiento y el precio por unidad ${ }^{14}$ :

- 200 piezas de piedra franca, de 2'5 x 3'5 x 5 palmos

- 600 carretadas de piedra sillar, de $2 \times 2$ × 5 × 3 palmos

- 200 carretadas de losas sillares, de 1'5 x 3 x 3 palmos

- 4 losas, de 9 × 3 palmos

- 400 cahices de cal

- 600 carretadas de arena

- 3.000 carretadas de piedra ripio, de 50 arrobas

Junto a los mencionados materiales, los artífices señalaron la necesidad de acopiar 1.000 estacas de madera y de disponer de 500 capazos para mortero, 300 para tierra, 12 calderas, 6 portadoras, 6 docenas de lazos, 4 docenas de cofas, una de legones, otra de palas de hierro, media de tablones de 20 palmos, 4 martillos, 4 mazas con sus argollas de hierro para fijar estacas, 4 pisones, 3 pares de ganchos, 2 perpalos, vigas y atocha, «adobar camins y ponts.... y altres coses moltes que segons la obra es descobriran seran menester». Entre enero y mayo de 1596 se fue haciendo acopio de todo el material, al objeto de comenzar las obras durante el estiaje, bajo la directa supervisión de los dos electos mencionados. Se ignora el número de peonadas que se emplearon en la fábrica del azud, pero no debió ser pequeño, ya que la obra se dio por acabada a principios de noviembre de 1598, casi tres años después de haberse contratado; y su coste total superó las 7.500 libras, que representaba el triple del precio de remate acordado dos décadas atrás, cuando su culminación resultó fallida ${ }^{15}$. Ahora, en cambio, se había realizado con el cuidado necesario y la utilización de los recursos precisos para dotarla de la requerida solidez que la hiciera capaz de resistir los periódicos embates

13. Los expertos «dixeren que lo azut que se entén a fer se deu construir on de present està lo açut vell en esta manera, fent li la cara al aygua de pedra picada y en mig del cos del açut de pedra ripio menuda ab morter ab piso y dalt al remat y cara del açut enllosat ab mascle y femella, començant lo açut de lo més fondo del riu al llivell de baix, y més si es podrà y per a que vaja a utilitat y seguritat convé ans y primerament comensarse a fer a la part del mont un valent malecó molt a dins de on prinsipie lo açut ab sos alerons y per mòdols en esfors y estrep del dit açut y est mes alt o al llivell dels bancals quexers del riu, del qual ha de exir lo trestallador ab ses branques y ben llosat per on ha de buydar el aygua del riu per a poderse obrar lo demés del açut». ARV: Real Audiencia. Procesos $1^{a}$ parte, S/1.748, f. 47-47v.

14. Ibidem, ff. 47v-51v.

15. Según cuentas presentadas por el electo Juan Sanz, se gastaron en la obra 7.432 libras, 11 sueldos y 4 dineros; pero a ello añadía otras tres partidas más, por un importe total de 265 libras, 1 sueldo y 6 dineros en concepto de salarios y alimentos de algunos operarios, que incluía a los agrimensores -sogejadorsque midieron las tierras irrigadas. Ibídem, ff. 27-35. También, AHO: Sec. Colegio, L-224, ff. 94v-97. 
de las crecidas del Segura. A ojos de los contemporáneos no había por qué temer ya nuevos contratiempos, «per ser la obra de aquell de traça y de art y la més utilosa y ben acabada que y ha en tota Espanya, a relació de persones expertes y que han vist molts edifficis fets y fabricats en rius y sobre aygua» ${ }^{16}$.

Atendiendo a la concreta ubicación del azud y a su complementariedad constructiva con el edificio anexo del molino de Alfaytamí, quedaba claro que uno de los primeros y mayores beneficiados de la fábrica de aquél habría de ser, necesariamente, el dueño de éste; pues vio reforzada la obra del mismo, incrementado el caudal que accionaba el mecanismo de la rueda de moler y garantizado el suministro del líquido elemento, prácticamente a lo largo de casi todo el año. Al parecer, como contraprestación por las ventajas obtenidas, el propietario del molino, además de ceder los terrenos que le fueron ocupados sin compensación, se habría comprometido a contribuir en los gastos como el resto de los regantes por el equivalente a 1.000 tahúllas de huerta. Sin duda, facilitó el acuerdo - que alteraba lo estipulado en la concordia de 1571- la estrecha relación mantenida con aquél por uno de los principales promotores de la obra y co-responsable de su traza definitiva. El Dr. Luis Ocaña, uno de los dos electos designados por la comunidad de regantes para llevar a cabo la dirección y el control de la fábrica del azud era, en efecto, tío y curador, por minoría de edad, de la hija de Gallicant, a la sazón dueña del molino. Y, tal como se le objetó posteriormente por sus émulos y enemigos, este parentesco no debió ser ajeno a la ubicación elegida para levantar la fábrica del azud, posiblemente en contra de la opinión de algunos regantes, que habían considerado la conveniencia de edificarlo aguas arriba, donde el cauce se estrechaba, para ahorrar costes ${ }^{17}$.

Pero, además del complejo formado por el molino y el azud anexo, las transformaciones operadas en el cauce del río no podían dejar de afectar al tradicional sistema de riegos de las huertas del entorno. Y es que éste era precisamente el medio imprescindible para conseguir el objetivo propuesto de ampliar el regadío y asegurar las dotaciones hídricas de las haciendas.

\section{LA REMODELACIÓN DE LA RED HIDRÁULICA}

La escasez, hasta el momento, de fuentes documentales suficientemente explícitas al respecto y la sorprendente ambigüedad e incluso aparentes contradicciones que muestran las referencias a la red de acequias que irrigaban las huertas de Almoradí y La Daya, antes y durante la construcción del azud de Alfaytamí, complican cualquier intento de ofrecer un panorama total y definitivamente cierto y seguro. Es fundamentalmente a partir de indicios -algunos de ellos, indirectos- que estaremos en disposición de aventurar cómo pudo ser la situación que presentaba el sistema de riegos vigente a mediados del siglo XVI para, en consecuencia, poder valorar mejor las transformaciones operadas a raíz de la edificación del azud.

16. Ibídem, f. $104 \mathrm{v}$.

17. Ibídem, ff. 13-20. 
Así, a partir de un padrón de regantes confeccionado en 1536 para toda la huerta del término general de Orihuela -entre otras varias fuentes disponibles-, es posible deducir que el diezmario de Almoradí y la baronía de La Daya se regaban a través de la denominada todavía Cequia de Almoradí-luego denominada Vieja-cuya toma se ubicaba en el casco urbano de la ciudad de Orihuela, y que se prolongaba a través de varios kilómetros, discurriendo muy cerca del cauce del río, por su margen izquierda, a la altura del molino de Alfaytamí. Seguramente en algún lugar no demasiado alejado de este enclave existiera un partidor que dividiera este acueducto al menos en dos brazales, de modo que uno de ellos -a veces denominado precisamente Alfaytamí o del Río- proseguía paralelo al río e irrigaba un total de 3.850 tahúllas, antes de desaguar directamente en el cauce fluvial. El brazal principal, de mayor recorrido, viraba hacia la izquierda en dirección noreste para atravesar el término de Almoradí en su parte central y recorrer el de Daya Nueva, hasta desaguar en los almarjales. En 1536 la denominada Cèquia de Almoradi dels partidors avall, que debía ser el nombre asignado a este último brazal, regaba 4.823 tahúllas en el diezmario de Almoradí, sin contar las atribuídas al Señor de la Daya, que se estimaron entonces en $4.000^{18}$. Sin disponer, por tanto, de una boquera directa del río -ya que procedía de la ciudad de Orihuela-, este brazal tenía tanda de sólo una semana, repartida por mitad entre los regantes de Almoradí, que la tomaban desde el domingo al atardecer hasta el amanecer del jueves, y el Señor de la Daya, que se beneficiaba los días restantes ${ }^{19}$.

Mas no era ésta la única gran arteria de irrigación que atravesaba la huerta de Almoradi. El mismo padrón de regantes registra la existencia simultánea en sus inmediaciones de más de una veintena de heredades, en su mayor parte de gran extensión, tributarias de la "Cèquia del Pla e del Riu de la horta de Guardamar, de Rojals amunt», que beneficiaba un total de 5.757 tahúllas y cuyo punto de captación de aguas resulta difícil de $\operatorname{situar}^{20}$. Por un lado, a juzgar por la fórmula indiferenciada con que ambas se mencionan de manera conjunta, podría tratarse aparentemente de dos brazales de un mismo acueducto madre cuya toma se ubicaría aguas arriba del molino de Alfaytamí. Pero ello plantea la exigencia de una boquera propia en el cauce del río, sobre cuya existencia no se dispone de ningún indicio; por lo que hay que descartarla. La otra alternativa, más plausible, consistiría en contemplarlas como dos brazales tributarios de la Acequia Vieja de Almoradí, que discurrían paralelos, suministrando el riego, a veces de forma compartida, a aquella veintena larga de heredades. Avalaría esta posibilidad la afirmación presentada -para su corroboración por testimonios cualificados- por las partes contendientes en un proceso suscitado entre regantes acerca de la obligaciones contributivas de la denominada heredad de Formentera. Ambos litigantes coincidían en reconocer -en 1610- que dicho patrimonio se había regado tradicionalmente «abans de la nova fàbrica del asut de

18. Archivo Municipal de Orihuela (en adelante, AMO): Libro $n^{\circ} 1.248$, ff. 472-477. La tahúlla mide $1.185 \mathrm{~m}^{2}$; de modo que $1 \mathrm{Ha}=8,4$ thas.

19. Canales Martínez, Gregorio y Muñoz HernándeZ, Remedios: «El Azud....», Op. cit., p. 86.

20. AMO: Libro $n^{\circ} 1.248$, f. 480. 
Alfaytamí, de la Cèquia Vella de Almoradì» que tomaba agua del Segura en la ciudad de Orihuela. Pero el síndico de la comunidad del azud precisaba que dicha heredad «abans de la segona y nova construcció del azut de Alfaytamí solia regarse del aygua del regolf de dit azut de Alfaytamí lo trencat per la Sèquia del Pla, que pren aygua de la Sèquia Major de Almoradi y Daya y axi es ver y encara consta per los patrons y taches de les mondes de dita Sèquia del Pla»; para puntualizar seguidamente, en otro ítem, que, en la actualidad -1610 - se regaba por mitad de dicha Acequia del Pla -800 tahúllas-y de la Acequia del Río -las 797 restantes $^{21}$. Quedaba aclarado, de esta guisa, que la boquera de dicha Acequia Mayor se había abierto antes de la construcción de la segunda y definitiva fábrica del azud, pero con posterioridad al primer intento fallido.

En ningún caso, finalmente, cabe identificar la Cèquia del Pla y del Riu que menciona el padrón de 1536 con la ya aludida acequia de $\mathrm{D}^{\mathrm{a}}$ Ana Rocafull a que se refería el Dr. Ocaña, cuya existencia individualizada viene corroborada -entre otras fuentes posteriores- por un padrón de regantes de toda la huerta confeccionado entre $1609 \mathrm{y}$ 1613. En este padrón figura, en efecto, dicha acequia de forma autónoma, irrigando 530 tahúllas de $\mathrm{D}^{\mathrm{a}}$ Ana y acogiendo también las heredades de Diego Limiñana y de Baltasar Pascual, que sumaban un total de otras 600 tahúllas más ${ }^{22}$.

Por relativamente incierta que resulte la situación preexistente a las obras derivadas de la fábrica del azud, más garantías de certidumbre parecen ofrecer los testimonios con que contamos a partir de ese momento acerca de las remodelaciones operadas en la red de irrigación. Así, la apertura de una boquera en el río para conducir el agua directamente a la nueva acequia de Almoradí y la Daya culminó, con toda seguridad, antes de 1593; por consiguiente, en tiempos anteriores a la construcción de la obra definitiva del azud. Más que de la apertura de un nuevo acueducto, se trataría fundamentalmente de aprovechar el cauce preexistente de la Acequia Vieja en su recorrido por los términos de Almoradí y la Daya, dotándole ahora de una conexión directa con el cauce fluvial para incrementar y regularizar su caudal, a pesar del carácter precario de la presa. La Cequia Nova de Almoradí se bifurcaba en dos ramales, a unos dos kilómetros de distancia de su boquera: uno de ellos discurría justamente por la antigua Cèquia del Pla, que conservó el mismo nombre; el otro, denominado Cèquia Mayor de Almoradí y Daya, de mayor recorrido, se correspondía con el viejo cauce homónimo. En conjunto, a la nueva Acequia de Almoradí, con sus dos ramales - del Pla y Mayor-se asignó tanda de 16 días, repartidos por mitad entre los términos de Almoradi y la Daya ${ }^{23}$.

Poco tiempo después de la apertura de este acueducto, pero siempre antes de 1593, comenzó a abrirse otra «boquera al riu de Sigura entre lo moli de Alfaytamí y boquera de Sèquia de Almoradí y Daya», para dotar de agua directamente del cauce fluvial a la denominada Acequia del Río, como acueducto ya claramente independiente, que discurría en paralelo al Segura, a mayor profundidad que la cola de la Acequia

21. ARV: Real Audiencia. Procesos $1^{a}$ parte, G/1.104, pássim.

22. AMO: Lib. $N^{o}$ 684. 1606-1616, ff. 46-114v.

23. AHO: Sec. Colegio. L-224, ff. 511-511v. 
Vieja de Almoradí, cuyo recorrido quedó sensiblemente acortado ${ }^{24}$. El 29 de septiembre de 1593 aún no habían finalizado las obras -iniciadas a instancias del recién fallecido Alonso de Leyva-, por lo que se decidió continuarlas, nombrando dos electos que habrían de encargarse de culminar «ab effecte la dita boquera y buch de sèquia engarcant dit nou edifici en lo antich de la Cèquia Vella de Almoradì» ${ }^{25}$.

Si la fabricación del azud generó una sustancial remodelación del sistema de riegos en la margen izquierda del Segura, sobre todo en lo que se refiere a las capturas de aguas de acueductos en buena parte ya existentes, tampoco al otro lado del cauce la situación habría de permanecer invariable. Tradicionalmente, la estrecha franja irrigada en la margen derecha era tributaria de las aguas proporcionadas por la Acequia de Alquibla, que, desde su boquera en la ciudad de Orihuela, se prolongaba hasta Guardamar a través de un largo cauce cuyo recorrido sobrepasaba los veinte kilómetros de longitud. Pero las expectativas generadas por la nueva fábrica de la presa debió alentar a algunos grandes propietarios de aquella otra margen del río para incrementar también las dotaciones hidricas de sus heredades. Una vez más, la autorizada descripción del Dr. Ocaña, en 1600, contribuye a desvanecer algunas incertidumbres al respecto, al asegurar que

«a causa de haver exit tan bona la construccion y fàbrica de dit açut se es segut que del regolf del açut al present pren aygua de aquell tres cèquies més, fora de la Cèquia de Almoradi y Daya, la primera cèquia es apellada de Alfaytami eo Cèquia del Riu, la segona cèquia es de Benijofer y la tercera cèquia de Dona Anna Rocafull»» ${ }^{26}$.

La apertura de la mencionada Acequia de Benijófar tampoco estuvo contemplada en los planes iniciales de la comunidad de regantes cuando se proyectó la fábrica de la presa en 1571. Era Benijófar una gran heredad - de extensión cercana al millar de tahúllas de huerta y un número indeterminado de secano-, con privilegio de dehesa, incluida a lo largo del siglo XVI en la zona de riegos de la Acequia de Alquibla. Su titularidad había pasado por sucesivas manos, hasta que en 1582 fue incorporada al patrimonio del Colegio de Predicadores de la ciudad de Orihuela ${ }^{27}$. Siempre atentos al modo más idóneo de rentabilizar sus dominios, los dominicos idearon muy pronto la construcción de un nuevo acueducto capaz de incrementar la dotación de agua con que irrigar su nueva adquisición, pues ni siquiera la existencia de una antigua noria -en la

24. En 1610 afirmaba un antiguo regante de dicho cauce -el dueño de Formentera, Ginés Jordi de Gascó-, sin duda exagerando, que, tras las remodelaciones operadas, «la Cequia Vella apellada de Almoradi no passa de les terres de Benejussern. ARV: Real Audiencia. Procesos $1^{a}$ parte, G/1.104, escritura de 16-III-1610, ítem 4. El acta del mencionado «consell de hereters regants de la Cèquia de Almoradi, de Benejusser en avall», de 1593, en AMO: Sobrecequier. Lib. 72, ff. 62-63v.

25. ARV: Real Audiencia. Procesos $1^{a}$ parte, G/1.104 f. $11 \mathrm{v}$.

26. ARV: Real Audiencia. Procesos $1^{a}$ parte, S/1.748 f. 104v-105.

27. Culí́Ñ̃z Celdran, Manuel C.: Benijófar. Historia de un municipio del Bajo Segura, Ayuntamiento de Benijófar, 2007, p. 52 y ss.; BERNABÉ GIL, David: «Sobre el origen territorial en los señoríos valencianos de colonización alfonsina», Señorío y feudalismo en la Península Ibérica (ss. XII-XIX), Institución Fernando el Católico, Zaragoza, 1993, III, pp. 134-135. 
ribera del río- para el servicio exclusivo de la heredad era capaz de suministrar el caudal complementario -al proporcionado por la acequia de Alquibla- que aquélla precisaba ${ }^{28}$. Las expectativas abiertas por la construcción del azud de Alfaytamí, aunque inicialmente destruido, quizás llegaron a resultar decisivas en la determinación que condujo a la mencionada adquisición patrimonial por parte del Colegio, si se toma en consideración la empresa acometida unilateralmente por los frailes hacia 1588 para mejorar el riego de Benijófar mediante la apertura de una nueva acequia que tomara agua de aquella presa; toda vez que la Acequia de Alquibla apenas era capaz de suministrarla a tanta distancia de su boquera y estaba sujeta a hurtos de todo tipo por parte de los regantes de arriba; y descartada claramente la otra alternativa por impracticable, pues «per la cenia o noria per on era lo rech de dita heretat de Benijofer no podria ara pendre's aqueducto per a regar dita heretat per estar aquella desfeta y haver mudat lo riu lo alveo» ${ }^{29}$.

La enorme lejanía de la heredad de Benijófar respecto del azud de Alfaytamí planteaba, sin embargo, el problema de la conducción del agua a través de una serie de heredades ajenas que, en conjunto, superaban los cinco kilómetros de distancia. El éxito de la empresa requería, por tanto, de la colaboración de los regantes cuyas tierras debía atravesar el proyectado acueducto. Mas no todos se mostraron dispuestos a permitir la apertura del nuevo cauce. Entre los principales regantes afectados por la decisión del Colegio sobresalía el propietario de la extensa heredad de la Algorfa, cuya huerta -mención aparte del amplio campo y dehesa anexa- sobrepasaba las 500 tahúllas. En nombre del heredero de dicha finca, y con el apoyo eventual de otros cuatro regantes afectados, Andreu Masquefa trató de oponerse judicialmente a los proyectos de los dominicos, haciendo ver que, además de los perjuicios que le ocasionaría en su patrimonio la excavación de una nueva acequia que habría de atravesarla, «per les resentiments e inundacions de aygues qu.es causaran en aquelles, per les quals se vindran a desflorar dites terres», resultaría menos costoso «exampliar la céquia de l'Alquibla y tallar arbres que estan per la vora de dita céquia», o incluso «pendre lo aqueducto mijantsant dita noria ${ }^{30}$.

Pese a la iniciales reticencias mostradas por algunos propietarios afectados por la apertura del nuevo cauce, tras la sentencia favorable al Colegio algunos de aquéllos acabaron renunciando al riego que recibían por la Acequia de Alquibla para acogerse al

28. Quienes se oponían a la apertura de esta nueva acequia -como se dirá más adelante- declaraban en 1589 que el Colegio ya tenía «dos aqueductos, lo hú de la cenia, que és lo antich per la qual dita heretat se solia regar, y lo de l'Alquibla, per los quals ab menos despesa pot regar dita heretat de Benijofer que la que causarà lo nou aqueducto que volen fer». ARV: Real Audiencia. Procesos de Madrid, A/177, escritura de 31-XI-1589.

29. Ibidem, sin foliar.

30. Ibídem. De los cuatro regantes que hicieron parte conjunta con el señor de Algorfa en el pleito contra el Colegio, dos se retiraron en cuanto se publicó la sentencia de la Audiencia, favorable al convento, y no apoyaron la subsiguiente suplicación ante el Consejo de Aragón. Otros permanecieron al margen, limitándose a percibir la indemnización correspondiente por las tierras ocupadas. Cfr. OJEDA NIETO, José: «Encauzamientos y mudamientos del río Segura en Orihuela durante los siglos XVI y XVII», en Cuadernos de Geografia, nº 79, Valencia, 2006, p. 11, nota 31. 
proporcionado por la de Benijófar, mediante el correspondiente acuerdo con su único dueño. Así, en 1614 los dominicos firmaban concordia con el propietario de la denominada heredad y casa de La Juliana y Torre de Fels, D. Salvador Boil y Masquefa, señor de la baronía de La Daya, para regar las 350 tahúllas de huerta de que constaba aquélla -además de muchas más de secano. D. Salvador renunciaba a las indemnizaciones debidas por las tierras que le habían sido ocupadas para excavar la nueva acequia, pero tendría derecho a 36 horas de agua cada semana, comenzando el lunes al amanecer. Se comprometía a pagar a los dominicos 1.000 reales de entrada y 200 cada año para los gastos de mondas y, en caso de que se hicieran obras en el azud de Alfaytamí y se le pasara al Colegio el cargo correspondiente -como propietario de la acequia-, a contribuir con las $3 / 14$ partes del mismo ${ }^{31}$. La acogida de la Juliana al riego de este nuevo acueducto debió producirse de forma efectiva, sin embargo, mucho antes de la mencionada concordia, pues figura como tributaria del azud ya en 1601; al tiempo que también lo hace a la comunidad de la Alquibla. La pertenencia simultánea de una misma heredad a dos comunidades de regantes distintas - pues podían utilizar el riego de ambas- también se aplica al caso de Benijófar, como atestiguan los padrones de regantes anteriores a 1622, en que las dos han renunciado ya al riego de la Alquibla ${ }^{32}$.

Y en 1616, otro particular -el ilicitano Jaume Ortiz- firmaba asimismo acuerdo con el Colegio, para poder acceder también -bajo ciertas condiciones, muy similares al caso anterior- al agua -en este caso, sobrante- de la Sèquia de Benijofer, con la que poder regar una heredad de 140 tahúllas $^{33}$.

Las transformaciones operadas en el paraje de Alfaytamí, así como las directamente inducidas por ellas a finales del Quinientos y principios de la centuria siguiente significaron, por tanto, una importante remodelación del complejo hidráulico asociado al azud, de imprevisibles consecuencias -que trataré en otro lugar. Objetivamente, se trataba de incrementar las dotaciones de agua para una zona a la que las viejas arterias nacidas en la lejana ciudad de Orihuela no conseguían abastecer ya lo suficiente. Al abrir nuevas boqueras en las proximidades de las huertas a irrigar se intensificaba su potencial productivo y se aumentaba su valor. Mas no todos los sectores implicados tenían los mismos intereses, más allá de las perspectivas de mejora generalizada que solían acompañar la presentación, ante las juntas de regantes, de aquellas iniciativas.

\section{SOBRE INTERESES EN JUEGO Y POSIBLES PROMOTORES}

Los cambios mencionados se insertan en una dinámica de expansión agraria que habría de manifestarse, asimismo, en otra serie de actuaciones a primera vista estre-

31. AHO: Sec. Colegio, L-224, ff. 576v-578.

32. AMO: Mingot. 1596-1624, ff. 111-117. No era infrecuente que las grandes heredades regaran de dos acequias distintas; como ya hemos visto también en Formentera.

33. Ortiz se comprometía a entregar al Colegio 150 libras, por una vez, y 200 reales anuales para los gastos de mondar, además de prolongar a su costa y mantener el cauce que pretendía abrir para llevar el agua a su heredad. Asímismo, se obligaba a contribuir en las derramas que estableciera la comunidad de regantes del azud de Alfaytami. AHO: Protocolos notariales de Diego León, 1616, escritura de 26-III-1616. 
chamente relacionadas con aquéllas. Es el caso, por ejemplo, de las tentativas de desecación de una zona de marjales colindantes con el tradicional perímetro de irrigación correspondiente a la Acequia de Almoradí y La Daya, que parecen concentrarse especialmente en los años comprendidos entre 1578 y 1582 . Durante este período, al menos 25 vecinos de la ciudad de Orihuela recibieron, en efecto, lotes de marjales de 200 tahúllas -algunos, de 400-, con la obligación de reducirlas a cultivo en un plazo de 5 años $^{34}$. De haberse cumplido en su totalidad los compromisos contraídos, ello hubiera supuesto la bonificación de un mínimo de 6.000 tahúllas, cuya inserción efectiva en la zona de riegos del azud de Alfaytamí habría aportado, en teoría, nuevos argumentos para justificar la remodelación hidráulica operada. Sin embargo, no está del todo clara la posible relación directa entre ambos procesos.

Por un lado, del grupo de beneficiarios de los almarjales, solo nueve llevaban apellidos que figuran en el primer padrón general conocido de regantes del azud, cual fue el de 1601. Tratábase, no obstante, en estos nueve casos, de individuos distintos, no necesariamente herederos patrimoniales, que -con la posible excepción de dosya poseían heredades en la zona antes de haber recibido los almarjales; las cuales se ubicaban generalmente, además, en partidas algo alejadas del humedal ${ }^{35}$. Por otro lado - y aunque pueda contemplarse como un argumento menor, por lo que más adelante se dirá- solo cuatro posibles herederos de aquellos 25 sujetos mencionados estuvieron presentes en las dos juntas generales de regantes celebradas en 1595, donde se decidieron la realización de las obras definitivas del azud y a las que asistieron un total de 80 hereters $^{36}$. Todo ello es indicio de que, en efecto, los almarjales no llegaron a gozar de la condición de heredades adscritas a dicha comunidad. Es más, la mayoría de concesionarios posiblemente no llevaron a cabo las inversiones necesarias para desecar efectivamente los terrenos recibidos. La conquista del almarjal requería

34. BERNABÉ GIL, David: «Insalubridad y bonificaciones de almarjales en el Bajo Segura antes de las Pías Fundaciones de Belluga (siglos XVI-XVII)», Revista de Historia Moderna, $\mathrm{n}^{\circ}$ 17, Alicante, 1998-99, espec. pp. 63-65.

35. Fueron beneficiarios de almarjales en 1579-82, entre otros: Miquel Bataller, Pere Carbonell, Miquel Gonsalvez, Micer Joan Jordi, Antoni Martí, Josep Orumbella, Gaspar y micer Francesç Parres y Francesç Rausell. Figuran, con dichos apellidos, como regantes del Azud de Alfaytamí en 1595 Ginés Bataller y en 1601: Joan Carbonell (10 thas), Andreu y Pere Gonsalvez (2 y 11 thas), Viuda de Ginés Jordi (1.940 thas, correspondientes a la heredad de Formentera), Andreu Martí (460 thas), Viuda de Orumbella (1 tha), menores de Gaspar Parres (305 thas) y Pere Rausell (803 thas). Con dichos apellidos, figuraban como regantes en la zona ya en 1536, la viuda de Francesç Carbonell (500 thas), herederos de Pere Gonsalvez (100 thas), Francesç, Jaume mayor, Jaume menor y viuda de Antonio Martí (165, 150, 150 y 154 thas) y Jaume Rausell (413 thas). Por consiguiente, parece difícil que los almarjales pudieran estar recogidos en la comunidad de regantes del azud tras su construcción. La identidad de los beneficiarios de los almarjales, en AMO: Contestador de 1578, ff. 92-99v; Contestador de 1579, ff. 8, 10-10v, 40, 89-90v; Contestador de 1582, ff. 3-3v, 37; la de los regantes en 1601, en AHN: Consejos. Leg. 21.930 ff. 47-51. Para 1535, AMO: $N^{o} 1.248$, ff. 472-477.

36. Se trataba de Ginés Bataller, la viuda de Pere Carbonell, Andreu Martí y Pere Rausell. La relación de asistentes a las juntas de regantes celebradas en 7 de marzo y 15 de octubre de 1595, en supra, notas 10 y 11 . 
un esfuerzo constante para conseguir desaguar las tierras inundadas -a través de la apertura de azarbes de avenamiento-, al tiempo que la prolongación de algún cauce preexistente -concretamente, las arrobas de las Parras o de los Gomares u otras hijuelas de la Acequia Mayor, por su izquierda, dada su ubicación- por el que recibir las aguas sobrantes para su irrigación. No parece probable, por consiguiente, que estas labores de bonificación llegaran a producirse realmente; al menos, de un modo lo suficientemente sostenido como para haber dejado su impronta, de manera relativamente permanente, en la estructura de la red de irrigación.

Entre los principales promotores de la idea de retomar la fábrica del azud de Alfaytamí difícilmente podemos incluir, por tanto, al grupo de beneficiarios de los almarjales; que habrían permanecido igualmente ajenos al planteamiento inicial de 1571-73. Es posible que las expectativas generadas inicialmente por la remodelación de la red hidráulica en la zona contribuyeran a impulsar algún tipo de estrategia bonificadora sobre esas áreas palustres que delimitaban, de forma fluctuante, su entorno. Pero no hay que olvidar, por otro lado, que se trataba de una operación auspiciada por el consistorio oriolano, de la que resultaron beneficiados individuos que tenían allí su residencia y que, además, mantenían estrechas relaciones con su oligarquía dirigente. Y esto era algo que seguramente llegó a suscitar algunas reticencias entre los regantes asentados en Almoradí.

Quizás no fuera casual que, precisamente en 1583, cuando los jurados de Orihuela estaban otorgando los últimos lotes de marjales en dicha zona, los habitantes de Almoradí obtuvieran de la Corona el privilegio de universidad separada. La consecución de esta modalidad de segregación municipal implicaba -entre otras cuestiones- la asignación del correspondiente término espacial, cuya concreta delimitación -mediante el preceptivo amojonamiento- se realizaba fundamentalmente a partir de dos vectores: el territorio comprendido en el tradicional diezmario parroquial y el número de vecinos asentados en la nueva entidad. Al emprender la vía segregacionista -a imitación de la vecina Callosa y de otras poblaciones valencianas algo más alejadas, también ubicadas en zonas de huerta, como Muchamiel o Carcagente-, los grupos hegemónicos de la sociedad almoradidense se hacían con el control de un espacio jurisdiccional propio, cual era el asignado -en lo que ahora nos ocupa- al sobrecequiero o juez de aguas - o, en su defecto, al justicia civil y criminal- y a la zona de riegos integrada en su demarcación ${ }^{37}$. Por consiguiente, si la conquista del almarjal podía resultar, en general, beneficiosa, era preferible dirigir y capitalizar los resultados de la actividad desecadora subsiguiente desde la entidad poblacional en cuyo seno habría de desarrollarse esa labor-Almoradí-, en vez de dejarla en manos de intereses un tanto externos, como eran los correspondientes a la ciudad de Orihuela. El proceso de segregación municipal emprendido por la nueva universidad podía cobrar así, en teoría, nueva dimensión. Sin embargo, en el amojonamiento del término asignado a Almoradí, la mayor parte de la

37. BERNABÉ GIL, David: «Universidades y villas. Notas sobre el proceso de segregación municipal en el realengo valenciano (siglos XVI y XVII)», Revista de Historia Moderna, 6/7, Alicante, 1988, pp. 11-38. 
zona de almarjales quedó finalmente al margen, permaneciendo incluida en territorio oriolano ${ }^{38}$.

Cercenada la posibilidad de controlar la gestión sobre buena parte de los almarjales, la jurisdicción obtenida por Almoradí habría de proyectarse irremisiblemente hacia la huerta tradicional. Pero para hacer aquélla realmente efectiva resultaba imprescindible disponer de edificios de irrigación propios; esto es, de azudes y boqueras de acequias ubicadas dentro de su demarcación; y, en consecuencia, de las correspondientes comunidades de regantes con funcionamiento autónomo. La consecución del título de universidad separada podía contemplarse así como el adecuado complemento de la remodelación hidráulica operada en Alfaytamí, pues permitía consolidar una comunidad de regantes propia, independiente de la Acequía Vieja de Almoradí -controlada por la oligarquía oriolana-, que actuaría ahora bajo la presidencia del sobrecequiero o el justicia civil y criminal, como oficios autónomos de la nueva entidad municipal.

Mas ello no quiere decir que la remodelación hidráulica integral aquí tratada respondiera exclusivamente a una estrategia orquestada por el vecindario de Almoradí para hacerse con el control definitivo de la zona de riegos de Alfaytamí y desplazar a los influyentes grupos oriolanos. Los promotores de la apertura de la Acequia del Río, por ejemplo, pertenecían en su mayoría al selecto grupo de la oligarquía oriolana, encabezados inicialmente por Alfonso Leyva, cuyo heredero figura en un padrón de 1601 como propietario de 972 tahúllas. Tras el fallecimiento de Alfonso, en efecto, cinco grandes hacendados de la Acequia Vieja decidieron, en junta celebrada en Orihuela el 29 de septiembre de 1593, bajo la presidencia del sobrecequiero de la ciudad, continuar hasta su culminación las obras ya iniciadas por aquél, nombrando síndico y electo en las personas de Andreu Soler y el Dr. Luis Ocaña ${ }^{39}$. Se trataba con ello, concretamente, de remediar «la gran falta de aygua que tenen en dita Cèquia, de Benejuser en avall, de tal manera que los fruits se perden e no poden regar per a sembrar, de tal manera que tenen ses heretats perdudes, fetes secans» ${ }^{40}$. Los intereses de estos grandes propietarios -y de otros regantes de la misma comuna- cuyos elevadas heredades apenas

38. MingueZ VALDÉS, Laura: «Un documento interesante», Almoradi, feria y fiestas, 1983, Ayuntamiento de Almoradí, 1983, sin pag. Se trata de la delimitación territorial asignada tras la obtención del privilegio de universidad.

39. Los cinco asistentes a la junta de regantes fueron: Micer Luis Ocaña; Mosén Luis Masquefa, como tutor de Nicolau Leyva -hijo del promotor-; Jaume Rois, hijo de Luis; Honorat Gil; y Andreu Soler, como procurador -y arrendatario- del Duque de Maqueda, poseedor por entonces de la heredad de Formentera, antes de que pasara a los Jordi. El padrón más cercano, realizado en 1601, les asignaba las siguientes propiedades: 717 tahúllas a Ocaña; 262, a Rois; y 1.940 a la hacienda otrora administrada por Soler, ahora poseída por Ginés Jordi; además de las 972 de Leyva. La información suministrada al respecto por el síndico del azud añadía otros ocho regantes interesados más, de la misma comuna, entre los que no faltaban grandes hacendados, como Pere Rausell, con 803 tahúllas; Rafael Durà, con 205; o los tres miembros de la familia Morsillo -Joan, Pere y Jaume- que acumulaban un total de 347 tahúllas. ARV: Real Audiencia. Procesos $1^{a}$ parte, G/1.104, ff. 11-11v; y AMO: Sobrecequiero. $N^{o} 72$; ff. 162-163, que contiene el acta original de la junta de regantes.

40. ARV: Real Audiencia. Procesos $1^{a}$ parte, G/1.104, ff. 11v. 
recibían agua por su acueducto tradicional, también estuvieron detrás de la decisión de reconstrucción definitiva del azud, como parece deducirse de su mayoritaria asistencia -8 casos de un total de 12 regantes conocidos- a las ya mencionadas juntas generales celebradas en 1595, en que se decidió emprender la nueva fábrica.

Por otro lado, la procedencia de una buena parte de los síndicos y electos de la comunidad del azud, durante y con posterioridad a las obras mencionadas -elegidos por sufragio por y entre todos los regantes, con independencia de la tierra poseída-, muestra una composición paritaria, a grandes rasgos, de los cargos directivos; cuando, de habérselo propuesto seriamente, los avecindados en Almoradí no habrían tenido grandes dificultades para monopolizar aquellos empleos, aprovechando su mayoría numérica y su lugar de residencia ${ }^{41}$. No es menos cierto que, incluso en algunos momentos decisivos, en que se adoptaron decisiones de hondo calado para la marcha de la comunidad, parece que no se convocó en debida forma a los avecindados fuera de Almoradí; de modo que eran los regantes que tenían más facilidad para informarse de la celebración de las juntas quienes encontraban menos dificultades para imponer en ellas su voluntad.

La ausencia de convocatoria expresa a los regantes forasteros para asistir a las juntas celebradas por la comunidad en su sede natural -la iglesia parroquial de San Andrés o la Plaza del Olmo de la universidad de Almoradí- y la adopción de decisiones por mayorías no cualificadas fueron asuntos polémicos, utilizados a veces como argumentos para impugnar sus efectos. Amparándose en la supuesta obligación del sobrecequiero de despachar correos a las poblaciones del entorno con suficiente antelación, alegaban -con desigual éxito- los afectados que, al no haber podido participar en la junta correspondiente por no haber sido notificada la convocatoria allí donde tenían su residencia, no se sentían vinculados a sus determinaciones y, en consecuencia, quedaban exentos de las consecuencias que de aquéllas se siguieran. Conjuntamente, en ocasiones, también sacaban a relucir que el número de asistentes representaba una pequeña proporción sobre el total de regantes empadronados; o que las tierras que aquéllos poseían eran comparativamente muy escasas; 0 , incluso, que en las votaciones nominales practicadas, la extensión patrimonial de los discordantes era superior a la de quienes apoyaban las mociones finalmente aprobadas.

A este tipo de argucias, que denotan una interesada concepción del voto de calidad, contraria a los usos y costumbres vigentes en la huerta -como se argumentó por la parte contraria-, acudió, entre otros, el Señor de la Daya para denunciar ciertas decisiones adoptadas por la comunidad en sesiones de cuya celebración supuestamente no había tenido conocimiento ${ }^{42}$. También el dueño de la extensa heredad de Formentera, natural de Elche y luego avecindado en Orihuela, hizo uso del mismo subterfugio aunque no fue éste su principal argumento- para tratar de sortear ciertos apremios por

\footnotetext{
41. Incluso parecen predominar los avecindados en Orihuela, al menos en los cargos de mayor relevancia, según se deduce de algunos datos parciales al respecto que he podido ir recogiendo de forma aleatoria.

42. AHN: Consejos, leg. 21.930, ff. 40-42.
} 
impago de derramas ${ }^{43}$. E incluso los propios síndicos del azud llegaron a utilizar este recurso para solicitar la nulidad de ciertas decisiones anteriores. En 1626, por ejemplo, se consiguió por este procedimiento invalidar la exención perpetua de contribuciones otorgada por la comunidad en beneficio del Dr. Ocaña en 1602, en premio por sus trabajos y servicios durante la fábrica del azud; aunque en 1639 no llegó a prosperar la pretendida impugnación -basada en similares supuestos- de una operación de reconversión de deuda suscrita por los regantes en $1610^{44}$.

Pero, en cualquier caso, y a tenor del desarrollo posterior de los acontecimientos, no parece que, en general, se planteara una significativa dualidad de estrategias y perspectivas en materia hidráulica entre los regantes, en función de su vecindad, como criterio determinante en última instancia. La condición de almoradidense o, por el contrario, de terratinent -como se denominaba a los propietarios forasteros- no debió ser un factor decisivo ni actuar como línea divisoria capaz de explicar por sí sola el protagonismo de los regantes en los proyectos de transformación hidráulica de la zona de Alfaytamí. Más plausible parece que, tal como señalara el señor de la Daya años más tarde, al tratar -inútilmente- de desmarcarse de los excesivos gastos ocasionados por las obras del azud, su ubicación y traza definitiva quizás no se realizara de la forma más conveniente para atender las necesidades reales de la mayor parte de los regantes -entre los cuales, naturalmente, él mismo se incluía-; sino para satisfacer las ambiciones personales del Dr. Ocaña, sus familiares y deudos y algunos grandes propietarios que encontraban serias dificultades en regar por el antiguo sistema, debido a la altitud de sus heredades. Aprovechando la ocasión para denunciar cómo «per haver massa aygua les terres de la Daya no donen tan bones collites y es fan almarjalenques»-lo que excluía, como hipotéticos beneficiarios, a los poseedores de almarjales- apuntaba, concretamente, además de al dueño del molino, hacia un grupo de potentados interesados en revalorizar sus patrimonios como propulsores de una innecesaria y contraproducente grandiosidad de la fábrica, que solo fue, en realidad, «en utilitat de unes terres altes y groses heretats de micer Luis Ocaña y de Leyva, y per a fer un moli que poseix Micer Remiro de Espejo, engañant ab estes apariencies al dit Don Salvador» ${ }^{45}$. Y en esta estrategia de presentarse como primera víctima de la obra, continuaba sosteniendo el heredero, años más tarde, que su predecesor había sido engañado para que aprobase la fábrica del azud, pues

«molts cavallers de Oriola, terratinents y que tenien terres li pregaren que consentis, ab presuposit de que a dit señor de la Daya no li hauria de venir dany y a ells y als de Almoradi los venia gran profit, per que per tenir les terres altes tenien gran falta de aygua, $y$ ab tot effecte, per ferlos plaer, consentí que es fes lo assut a la part damunt de hon està construit, ab pacte que lo dit assut no fos de sis pams en amunt y en part mes comoda y de menis gast y no en lo puesto que hui està» ${ }^{46}$

43. ARV: Real Audiencia. Procesos $1^{a}$ parte, G/1.104.

44. ARV: Real Audiencia. Procesos $3^{a}$ parte, $n^{\circ} 2.377$, pássim.

45. AHO: Sec. Colegio, L-224, ff. 169-169v.

46. Ibidem, f. 511. 
El argumento acerca del desmesurado encarecimiento de la obra también fue utilizado por el propio síndico de los regantes -en un proceso contra Ocaña acerca de su rendición de cuentas- al tratar de demostrar, además de la afirmación anterior, la deficiente gestión económica realizada, tanto en la contratación de los asalariados que trabajaron en el azud, como en la provisión del material y pertrechos empleados. A través de una detallada información acerca de la cuantía de los jornales acostumbrados en la zona para cada una de las especialidades laborales con participación en las obras y de las cantidades realmente pagadas por Ocaña por no haber sabido negociar correctamente, se trataba de hacer ver los injustificables excesos en que había incurrido. Directamente, se le acusaba también de haber empleado una parte de aquellos jornales y materiales en adecentar gratuitamente la propia casa de labranza que poseía en la huerta de Almoradí. Finalmente, se le atribuía no poca inoperatividad a la hora de hacer contribuir a determinados regantes, haber consentido en la exención de algunos -incluidos él mismo y su sobrina, como propietaria del molino, contrariamente a lo acordado-, haber multiplicado innecesariamente los gastos procesales en otros casos; haberse embolsado excesivos emolumentos por su gestión como electo del azud; hacer dejación de la redención de capitales y del pago de intereses, arrastrando a un endeudamiento desproporcionado a la comunidad de regantes; $y$, en fin, se le hacía cargo de haber hecho un pésimo -e incluso fraudulento- uso de los poderes recibidos ${ }^{47}$. Todo ello habría sido posible -según testificaban algunos- merced al apoyo y complicidad de una parte del vecindario almoradidense, facilitado por las relaciones familiares establecidas con los Girona - pues Ocaña estaba casado con una dama de este apellido, de nombre Isabel-, y de patrocinio y clientelismo con algunas amistades de éstos, como los Guterris ${ }^{48}$.

Pero, ¿realmente habían llegado a alcanzar magnitudes tan alarmantes los costes globales de las obras realizadas? Según cuentas presentadas por el Dr. Ocaña en 1602, para la financiación del azud se fueron cargando censales entre 1595 y 1599 por un importe total de 9.596 libras de propiedad, algunas de las cuales se destinaron a redimir censales iniciales y otras -en ambos casos, de no muy elevada cuantía-, a gastos generados por pleitos contra regantes remisos a contribuir en las derramas anuales que fueron impuestas para atender la deuda. La urgencia de contar con los capitales necesarios con la máxima rapidez, además de la desfavorable coyuntura por la que atravesaba el mercado de empréstitos, influyó seguramente en el elevado tipo de interés que hubo que pagar por aquéllos, situado en todos los casos en el 10 por ciento anual. Un total de 19 prestamistas, en su mayor parte pertenecientes a la oligarquía y al clero oriolanos -y también algunos ilicitanos- suministraron, a través de 29 censales, la liquidez

47. ARV: Real Audiencia. Procesos $1^{a}$ parte, S/1.748, ff. 13-20.

48. Según afirmaba el señor de la Daya «en dita universitat de Almoradi no.s feya més de lo que volia lo dit doctor Don Luis Ocaña, al qual dien y nomenaven lo señor Miser Ocaña y el reputaven tant com si fora señor de dita universitat y feia juntar lo consell de dits hereters tots temps y quant pereixia ad aquell, parlant a tots sos amichs y parents per a que.s trobassen en lo consell». AHN: Consejos, Leg. 21.930, ff. $34 \mathrm{v}$. 
necesaria para llevar a cabo las obras y atender todos los gastos colaterales que aquéllas conllevaron. Entre los financieros no faltaban grandes propietarios de huerta -como Joan Cascant, que con cerca de 600 tahúllas de riego en la zona aportó por sí mismo y como administrador de menores un total de 1.830 libras-; y solamente entre cinco de aquéllos facilitaron la mitad del capital ${ }^{49}$.

En principio, la liquidación de los empréstitos contraídos, aunque ciertamente onerosa para los regantes, no debía resultar inasumible, si se tiene en cuenta que el total de tahúllas empadronadas en 1601 ascendía a cerca de 23.000 -incluidas las 1.000 asignadas, por equivalencia, al molino de Alfaytamí-; lo que significaba una cuota teórica media inferior a los 9 sueldos por tahúlla ${ }^{50}$. Un siglo más tarde, sin embargo, los créditos que pesaban sobre la comunidad del azud se aproximaban a las 22.000 libras de principal. Las razones de esa desproporcionada diferencia se tratarán en otro lugar; pero, en su complejidad, no fueron ajenas a ciertos problemas derivados de algunas características que presentaban las estructuras agrarias o ligados a su percepción.

\section{INTENSIFICACIÓN DEL RIEGO Y DINÁMICA DE LA PROPIEDAD}

El conjunto de actuaciones hidráulicas acometidas en la zona de Alfaytamí habría permitido, por un lado, incrementar y asegurar las dotaciones hídricas a un buen número de patrimonios que ya venían formando parte del perímetro habitual de irrigación; pero, también, conducir el agua hasta parcelas -o partes de ellas- que hasta ese momento apenas podían beneficiarse. La previsible ampliación de la huerta que habrían acarreado aquellas obras resulta, sin embargo, difícil de cuantificar; a pesar de la existencia de sendos padrones de regantes confeccionados en 1536 y 1601 . El análisis de este último no ofrece problema alguno, puesto que recoge la totalidad de heredades tributarias al conjunto de acequias beneficiadas por el azud de Alfaytamí, sin individualizar más que el nombre de sus propietarios y la extensión de tierra asignada a cada uno. La suma de todas ellas arrojó, así, la cifra de 21.924 tahúllas en la margen izquierda; de las cuales 6.990 correspondían a la Daya ${ }^{51}$.

El padrón de 1536, confeccionado cuando se estaba iniciando una coyuntura agraria expansiva, se anticipa demasiado tiempo al momento previo a la remodelación hidráulica que comentamos; lo que reduce un tanto su virtualidad como referente comparativo, si lo que se pretende es medir el impacto inmediato de aquélla. Pero es que, además, la forma en que se realizó plantea algunas dificultades de interpretación; de modo que la solución que adoptemos para tratar de resolverlas influye sensiblemente en la valoración final. Distingue el mencionado padrón -que abarca toda la huerta del término general de Orihuela- en lo que ahora interesa, tres zonas de riegos cuya amplitud, en conjunto, vendría a aproximarse a la correspondiente posteriormente al azud de Alfaytamí. Descontando las 4.000 tahúllas asignadas a la Daya, nos ofrece

49. ARV: Real Audiencia. Procesos $1^{a}$ parte, S/1.748, ff. 50-57v.

50. AHN: Consejos. Leg. 21.930, ff. 47-51.

51. Ibidem. 
así, por un lado, la relación de heredades integradas en la «Sèquia de Almoradí, dels partidors avall», que hacen un total de 5.113; por otro, «les tafulles del terme de la vila de Guardamar de la Sèquia del Pla e del Riu», que suman 5.757; pero también las irrigadas por la Acequia Vieja de Almoradí, en «Alfaytami», que ascienden a $3.850^{52}$. En los dos primeros casos, las heredades incluidas tuvieron que quedar integradas necesariamente en la comunidad del Azud cuando ésta se constituyó; pero de las tahúllas anotadas en Alfaytamí es muy posible que algunas aun permanecieran bajo riego de la Acequia Vieja después de $1598^{53}$. Aceptando la extensión correspondiente a los tres sectores mencionados, en su totalidad, como equivalente al territorio luego tributario del Azud, la suma obtenida para 1536-14.420 tahúllas- resultaría demasiado cercana a la proporcionada por el padrón de 1601 -que anota 14.934, descontando siempre Benijófar y la Juliana, tradicionalmente irrigadas por la Acequia de Alquibla, que discurría por la margen derecha. Admitir sin más esta valoración supondría que, lejos de procurar una significativa ampliación del regadío, las remodelaciones del último cuarto de la centuria, que debieron estar precedidas por algunas conquistas anteriores no imputables directamente a la fábrica del azud, se tradujeron a fin de cuentas en un avance casi imperceptible de la huerta.

La posible continuidad de algunas haciendas de Alfaytamí en el riego de la Acequia Vieja, aun después de 1598 -lo que las excluiría del padrón de 1601-, no tuvo suficiente calibre como para explicar ese aparente e impredecible estancamiento relativo. Quizás contribuyera igualmente a mantener esa ligera diferencia, en alguna medida, la posible asignación íntegra al riego de Almoradí, en 1536, de algunas grandes heredades ubicadas en el límite de su zona de influencia, pero que también irrigaban por otros acueductos procedentes de otros sistemas hidráulicos vecinos, como era el correspondiente al azud de Rojales, situado aguas abajo. Podría ser el caso del extenso patrimonio, calculado en 2.000 tahúllas y así anotado en 1536 en la Cèquia del Pla y del Riu, al magnífich Pere Masquefa, quien vuelve a figurar, además, en el mismo padrón general, con otras heredades tributarias del mencionado azud en las acequias de Los Huertos -400 tahúllas-, la Alcudia -66 tahúllas- y el azarbe de la Reina -300 tahúllas-; todas ellas tachadas, significativamente, en los asientos correspondientes. Al tratarse de un padrón general de todo el Bajo Segura, no importaba tanto en qué comunidad de regantes se inscribía cada patrimonio. El problema podía surgir cuando cada comunidad decidía de forma autónoma aplicar una derrama propia -como era lo habitual- y computaba a este tipo de heredades de riego compartido la totalidad de su

52. AMO: $N^{o} 1.248$, ff. 472-477.

53. Aunque no fue esto lo normal. Entre los patrimonios contabilizados en Alfaytamí en 1536 figuran los correspondientes a los regantes mencionados en la junta de 1571 como sujetos a posibles indemnizaciones por tomarles parte de sus tierras para las obras del azud: Frances Gallicant, Frances Martí y Nicolau Cascant, seguramente padre de Jaume y Bertomeu. Y también lo hacen varios vecinos de Almoradí -expresamente indicados- como Francesç Viudes y Frances Agullana, y algunos más de estos apellidos. Asímismo, los Rausell, Martí, Ardit, Sans, Cecilia repiten, junto con los ya señalados, como propietarios en Alfaytamí en 1536 y, luego, en la comunidad del azud en 1601. 
extensión ${ }^{54}$. Como tercer elemento a tener en cuenta cabe aludir también, finalmente, a la posible imprecisión o errores de apreciación de los agrimensores o encargados de elaborar los padrones cuando se enfrentaban con la tarea de cuantificar las dimensiones de las grandes heredades o, más concretamente, de las zonas de riego efectivo; y, en relación con ello, al efecto multiplicador de cierta tendencia al redondeo de la cifras, que parece mucho más acusada en $1536^{55}$. En consecuencia, no cabe descartar que la extensión total de huerta obtenida a partir de los datos del padrón de 1536 esté algo sobrevalorada; aunque sea en muy pequeña proporción.

No ocurre lo mismo, sin embargo, con los tres grandes dominios que hemos obviado expresamente en este balance, donde las diferencias de cómputo sí revelan claramente, por el contrario, una apreciable ampliación del regadío. Así, a la baronía de la Daya se asignan solo 4.000 tahúllas en 1536, mientras que en 1601 se contabilizan exactamente 6.990. Y otro tanto podría decirse de la heredad de Benijófar, que figura en el padrón de 1536 con 500 tahúllas irrigadas, mientras que en 1601 contribuye por 1.065; y, aunque en menor proporción, de la Juliana-Torre de Fels, cuyo riego se extendía en la primera fecha a 300 tahúllas, pero aparece en la última con 368.

En general, y con la prudencia que aconseja el tratamiento de estas fuentes, solo cabe atisbar, por tanto, un ligero incremento del perímetro de irrigación como consecuencia de la construcción del azud, que -como ya se ha dicho- apenas llegaría a afectar a la zona de almarjales; o, al menos, a los otorgados por la ciudad de Orihuela. El conjunto de las remodelaciones operadas en la zona dependiente del azud habría tenido así, como principal consecuencia, el incremento de las dotaciones hídricas en espacios tradicionalmente ya asignados, pero que, a veces por su difícil posición, no siempre podían acceder al riego en condiciones similares a las de las tierras mejor situadas. La proximidad del saladar y del almarjal, las diferencias de altitud, por pequeña que ésta fuera, las variaciones edafológicas del suelo e incluso la disposición de las diversas zonas de una misma heredad respecto a la toma de agua y al avenamiento eran elementos que, junto a la aplicación y cuidados del cultivador, podían determinar una sensible gradación en la operatividad real del regadío. Estos factores, pero también otros relacionados con las cargas contributivas que recayeron sobre los patrimonios, explicarían en buena parte las diferentes estimaciones de las dimensiones asignadas a las heredades, sobre todo en el caso de las más extensas; como se aprecia más claramente en varios padrones realizados en las tres primeras décadas del Seiscientos ${ }^{56}$. El

54. También la heredad de Formentera era tributaria del azud de Rojales, pues a principios del siglo XVII los padrones de esta comunidad le asignaban en torno a 900 tahúllas de riego. AMO: Sobrecequiero. $N^{o}$ 71, ff. 340-341; $N^{o} 76$, ff. 105-108.

55. En relación con esta imprecisión cabe añadir, además, que para la Cèquia del Pla y del Riu se realizaron dos padrones paralelos en 1536, y en nueve ocasiones no coincide el número de tahúllas asignadas a sus respectivos propietarios. Puesto que en el primero de ellos figura al margen la anotación «no», hemos dado por bueno el segundo, en cuyo margen puede leerse precisamente la anotación «si».

56. Que serán objeto de atención, en otro trabajo propio en preparación sobre «Los regantes del Azud de Alfaytamí durante el siglo XVII». 
cálculo sobre las oscilaciones experimentadas por el perímetro de irrigación a lo largo del tiempo se ve dificultado, además, por el predominio de la mediana y la gran propiedad, que multiplica los efectos de las diferencias de cómputo.

La distribución de la propiedad de la tierra en la zona objeto de estudio muestra, en efecto, un elevado grado de concentración que, con la expansión del Quinientos, parece experimentar pocos cambios sustanciales. Cierta tendencia a la fragmentación de los patrimonios - no ajena al crecimiento demográfico ${ }^{57}$-, especialmente acusada en los niveles inferiores, pero tampoco del todo ausente en el grupo de la media-alta propiedad, explica el incremento del número de regantes -de 117 a 171-a lo largo de las seis décadas y media que separan ambos padrones. Son fundamentalmente los pequeños huertanos, muchos de los cuales se sitúan por debajo del límite de la subsistencia, los que experimentan el mayor crecimiento numérico y, con ello, reducen el tamaño medio de sus parcelas. La mitad de los regantes del azud poseían heredades inferiores a las 2,5 hectáreas; mientras que, en el otro extremo, casi la mitad de la huerta se la repartían entre sólo una decena de propietarios -siempre, sin contar la Daya, Benijofar y la Juliana-.

Tampoco resultó desconocida en la huerta de Almoradí, sobre todo antes de la construcción del azud, la figura del labrador acomodado, que en algunos casos no pudo evitar la progresiva fragmentación de sus heredades, pero en otros consiguió aprovechar las favorables coyunturas para conservar e incluso incrementar sus dominios. A pesar de alejarse un tanto de sus posiciones de antaño, a principios del Seiscientos al menos uno de cada cuatro regantes todavía poseía tierras suficientes como para permitirse vivir, a priori, si no con demasiados lujos, sí al menos con cierto desahogo.

Pero son las grandes heredades las que se erigen desde un principio en verdaderas protagonistas de la huerta; y aunque con el paso del tiempo van reduciendo su número, aumentan de tamaño. Se trata en ambas fechas, en su mayoría -las dos terceras partes-, de patrimonios en manos de terratenientes forasteros, generalmente afincados en la ciudad de Orihuela, que no siempre consiguen, sin embargo, mantener íntegramente estas grandes heredades en la misma línea familiar. La continuidad de la gran explotación no es incompatible con su traspaso a otros linajes, que continúan siendo mayoritariamente forasteros; y entre los cuales no es difícil encontrar algunos promotores de las obras del azud. Una simple comparación entre los mayores hacendados en ambas fechas quizás pueda resultar ilustrativa de esta ambivalencia. Y esa enorme proporción alcanzada por la propiedad forastera también afectó, aunque en mucha menor medida, al grupo de la mediana propiedad, contribuyendo así a una relativa devaluación, en Almoradí, de la figura del labrador acomodado.

Aunque individualmente considerados tampoco faltan residentes en Almoradí que sobresalen como propietarios, algunos clanes familiares también llegaron a controlar patrimonios de cierta envergadura. En 1536 destacan los Girona, cuyos 9 representan-

57. Sobre la trayectoria demográfica, vid. OJEDA NIETO, José: «Almoradí en el siglo XVI. Apunte sociodemográfico», Alquibla, nº 6, Orihuela, 2000, pp. 515-539. 
tes se reparten un total de 1.080 tahúllas, y los Agullana, con 6 miembros y un total de 963 tahúllas. También los Viudes, aunque son sólo tres, acumulan 574 tahúllas; mientras que los 9 regantes que llevan Sánchez de apellido no consiguen acaparar más de 357. Casi tres generaciones más tarde, los Girona mantienen su presencia, con otros 9 miembros, pero sus patrimonios han disminuido a menos de la mitad, pues solo contabilizan 490 tahúllas; mientras que aparecen, más modestamente, los Morsillo, cuyos 3 representantes acumulan 347 tahúllas; los Ardit, con 7 miembros y solo 267 tahúllas; o los Martinez, que agrupan a 12 regantes -seguramente distribuidos en varias ramas familiares- y 591 tahúllas. Junto a los escasos individuos anotados en la lista de mayores herederos, parece haberse configurado una modesta clase media no demasiado numerosa que, en general, tiende a perder protagonismo a lo largo del Quinientos.

En cierta medida, la apertura de las boqueras de las acequias y la fábrica del azud vendrían a ser también la respuesta de este sector de almoradidenses todavía acomodados, pero que empezaba a encontrar algunas dificultades para mantener el tamaño de sus fincas de antaño; y, al mismo tiempo, la expresión de los deseos de promoción de algunas nuevas familias que venían ascendiendo. El estudio de la dinámica experimentada por la comunidad de regantes a lo largo del Seiscientos mostrará hasta qué punto se cumplieron las expectativas puestas en las obras que aquí han sido objeto de atención.

Distribución de la propiedad de la huerta en 1536

(Acequias de Almoradi y del Pla y Rio y Alfaytami)

\begin{tabular}{|c|c|c|c|c|c|}
\hline Hectáreas & Tahúllas & $\mathbf{N}^{\mathbf{0}}$ Prop. & $\mathbf{\%}$ & $\mathbf{N}^{\mathbf{0}}$ Thas. & $\mathbf{\%}$ \\
\hline $0-1$ & $0-8$ & 16 & 13,6 & 75 & 0,5 \\
\hline $1-2,5$ & $9-21$ & 27 & 23,1 & 413 & 2,9 \\
\hline $2,5-5$ & $22-42$ & 13 & 11,1 & 429 & 3,0 \\
\hline $5-10$ & $43-84$ & 14 & 12,0 & 805 & 5,6 \\
\hline $10-25$ & $85-210$ & 26 & 22,2 & 3.745 & 26,0 \\
\hline $26-50$ & $211-420$ & 17 & 14,5 & 5.443 & 37,6 \\
\hline $50-100$ & $421-840$ & 3 & 2,6 & 1.510 & 10,5 \\
\hline+100 & +840 & 1 & 0,9 & 2.000 & 13,9 \\
\hline TOTAL & & 117 & 100 & 14.420 & 100 \\
\hline
\end{tabular}

Fuente: AMO: $N^{o} 1.248$, ff. 472-477. Elaboración propia. Sin incluir La Daya 
Distribución de la propiedad de la huerta en 1601

(Acequia nueva de Almoradi y del Pla y Rio)

\begin{tabular}{|c|c|c|c|c|c|}
\hline Hectáreas & Tahúllas & $\mathbf{N}^{\mathbf{0}}$ Prop. & $\mathbf{\%}$ & $\mathbf{N}^{\mathbf{0}}$ Thas. & $\mathbf{\%}$ \\
\hline $0-1$ & $0-8$ & 49 & 28,7 & 219 & 1,5 \\
\hline $1-2,5$ & $9-21$ & 36 & 21,1 & 455 & 3,0 \\
\hline $2,5-5$ & $22-42$ & 23 & 13,5 & 739 & 4,9 \\
\hline $5-10$ & $43-84$ & 24 & 14,0 & 1.460 & 9,8 \\
\hline $10-25$ & $85-210$ & 24 & 14,0 & 3.482 & 23,3 \\
\hline $26-50$ & $211-420$ & 6 & 3,6 & 1.626 & 10,9 \\
\hline $50-100$ & $421-840$ & 7 & 4,0 & 4.050 & 27,1 \\
\hline+100 & +840 & 2 & 1,1 & 2.909 & 19,5 \\
\hline TOTAL & & 171 & 100 & 14.934 & 100 \\
\hline
\end{tabular}

Fuente: AHN: Consejos. Leg. 21.930, ff. 47-51. Elaboración propia. Sin incluir La Daya.

\begin{tabular}{|l|c|l|c|}
\hline \multicolumn{2}{|c|}{$\begin{array}{c}\text { Grandes herederos en 1536 } \\
\text { (Ac. Almoradi, Pla y Riu y Alfaytami) }\end{array}$} & \multicolumn{2}{c|}{$\begin{array}{c}\text { Grandes herederos en 1601 } \\
\text { (Acequia Nueva de Almoradí, Pla y Riu) }\end{array}$} \\
\hline Pere Masquefa & 2.000 & Vda. de Ginés Jordi & 1.937 \\
Llois Rois & 550 & Nicolau Leiva & 972 \\
Vda. de Francesç & & Luis Marti & 793 \\
Carbonell & 500 & Dr. Luis Ocaña & 716 \\
Hereus de Andreu Miro & 460 & Joan Cascant & 588 \\
Jaume Rausell & 413 & Pere Rausell & 533 \\
Jaume Agullana & 400 & Jaume Tari & 480 \\
Nicolau Cascant & 400 & Da Ana Rocafull & 472 \\
Joan Sans menor & 400 & Andreu Marti & 460 \\
Josep Silvestre & 400 & Menores de Gaspar Parres & 305 \\
Joan Vilafranca & 400 & Joan Sans & 300 \\
Vda. FrancesçAgullana & 360 & Vda. de Gallicant & 278 \\
Garci Ferrandez de Tuesta & 340 & Jaume Rois & 262 \\
Francesç Gallicant & 338 & Joan Martinez de Xea & 253 \\
Gines Viudes & 314 & Joan del Rio & 230 \\
Andreu Miro & 300 & & \\
Sancho de Leyva & 300 & & \\
Herederos de Andres & & \\
Arnal & 250 & & \\
Vda. de Joan Soler & 243 & & \\
Baltasar Viudes & 230 & & \\
Francesç Martí & 230 & & \\
D. Pedro Rocafull & 225 & & \\
\hline
\end{tabular}

En negrita: Regantes con el mismo apellido en ambas fechas

En cursiva: Residentes en Almoradí 


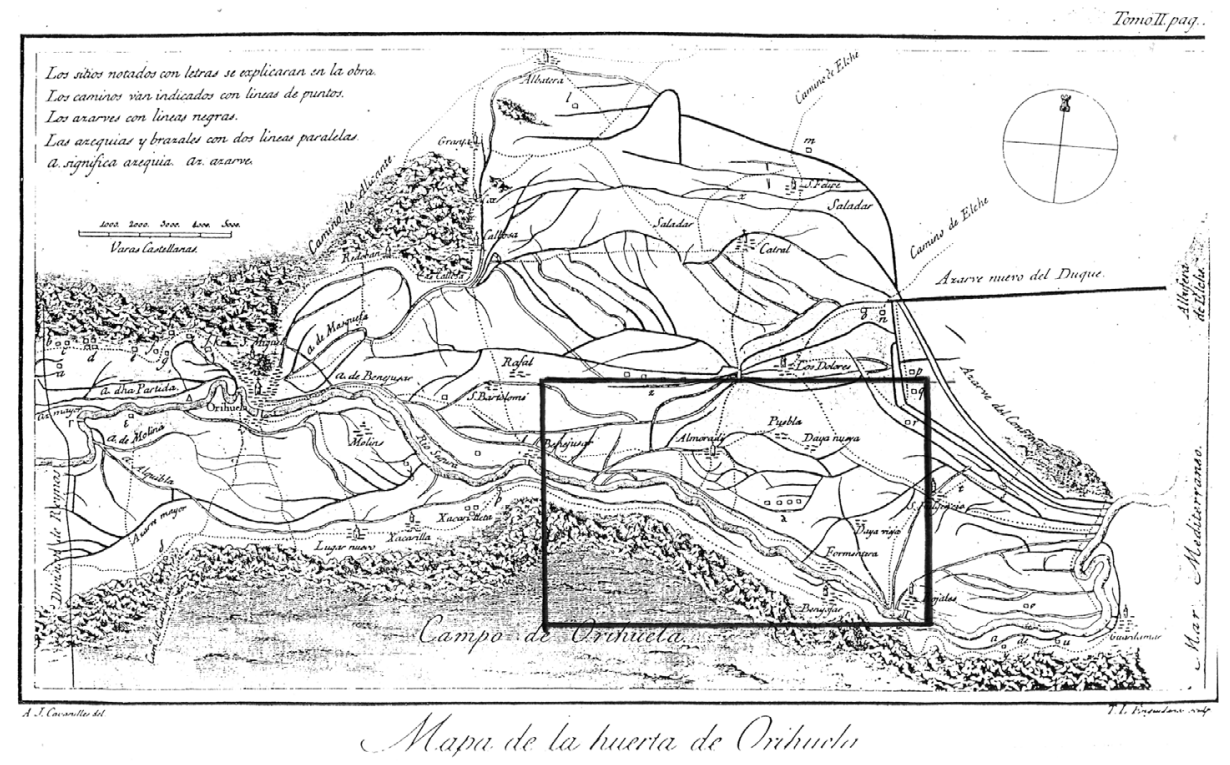

Mapa de la huerta de Orihuela, según Cavanilles (1797) 


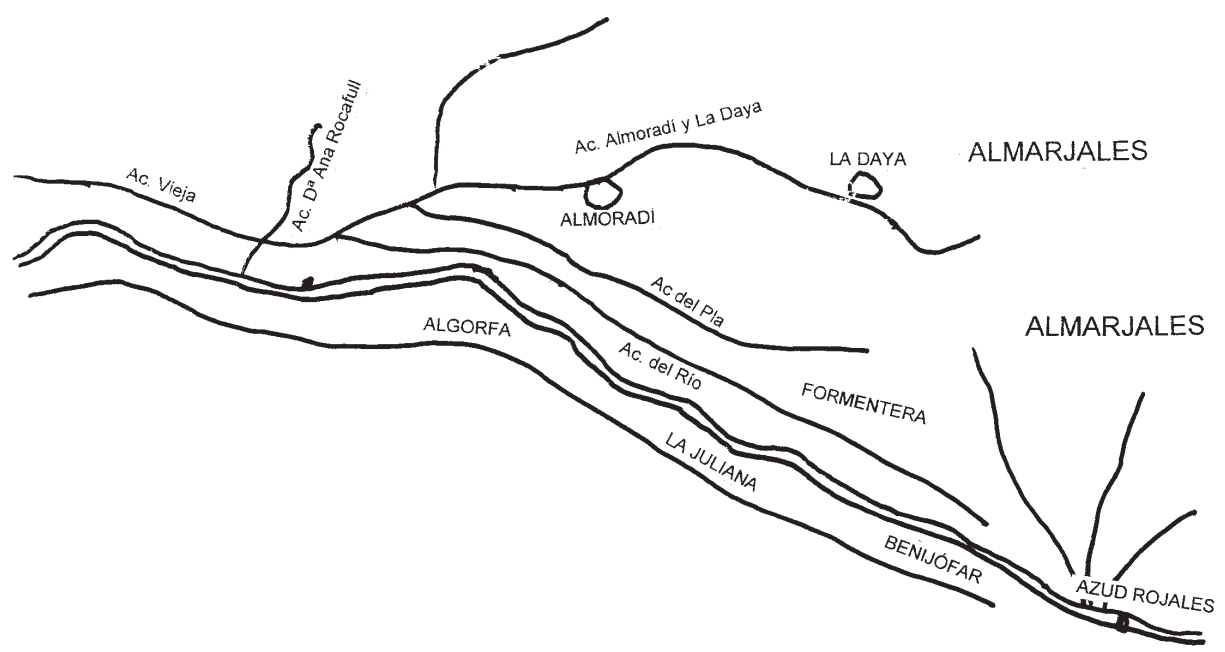

La red de acequias antes de la construcción del Azud de Alfaytamí.

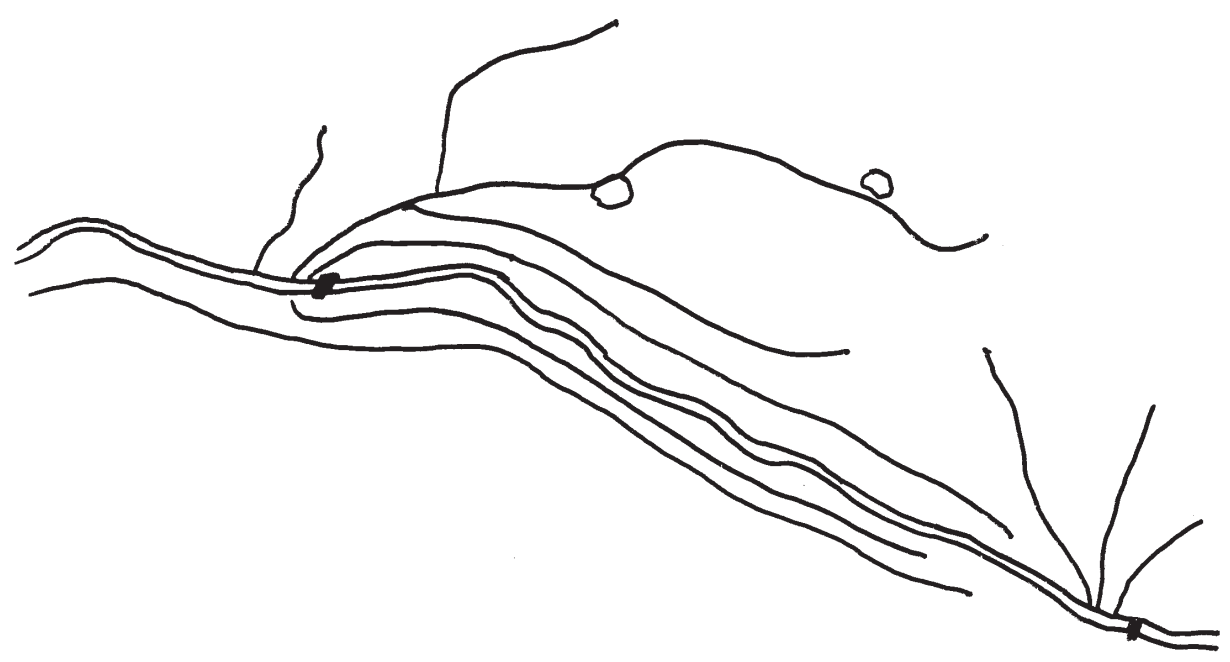

La red de acequias después de la construcción del Azud de Alfaytamí. 


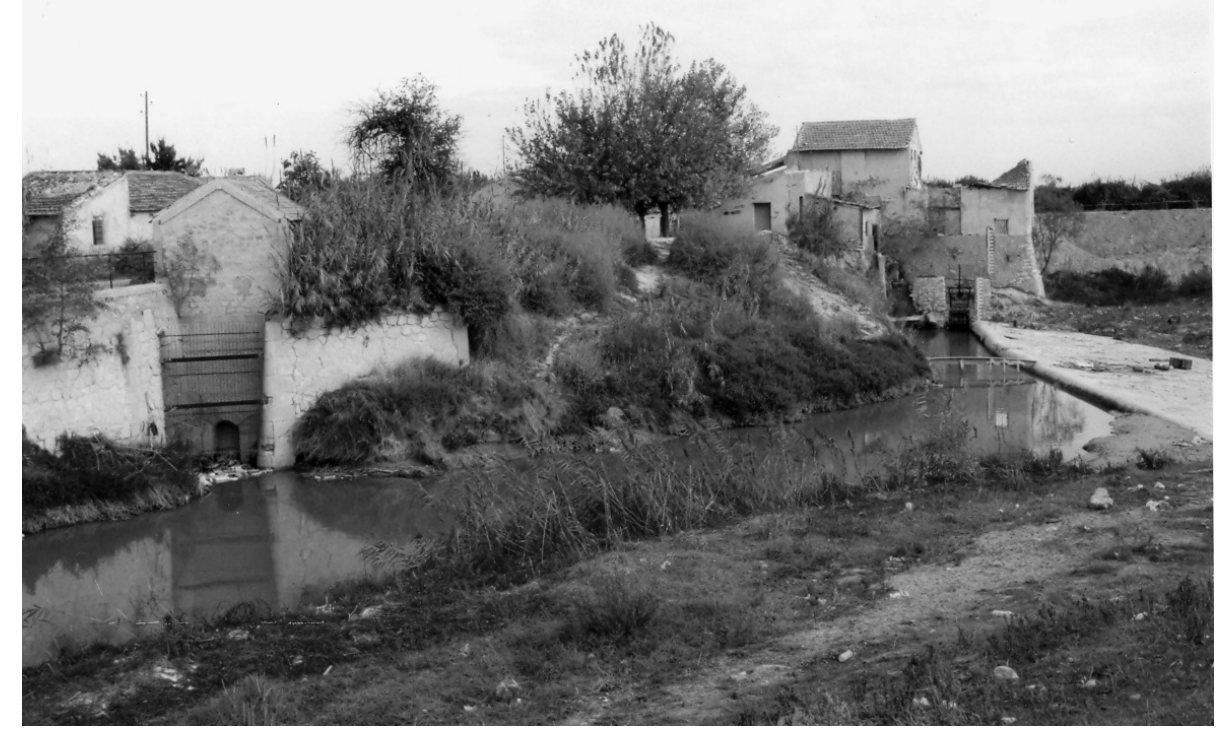

Azud de Alfataymí, molino y boquera de la Acequia del Río (1990)

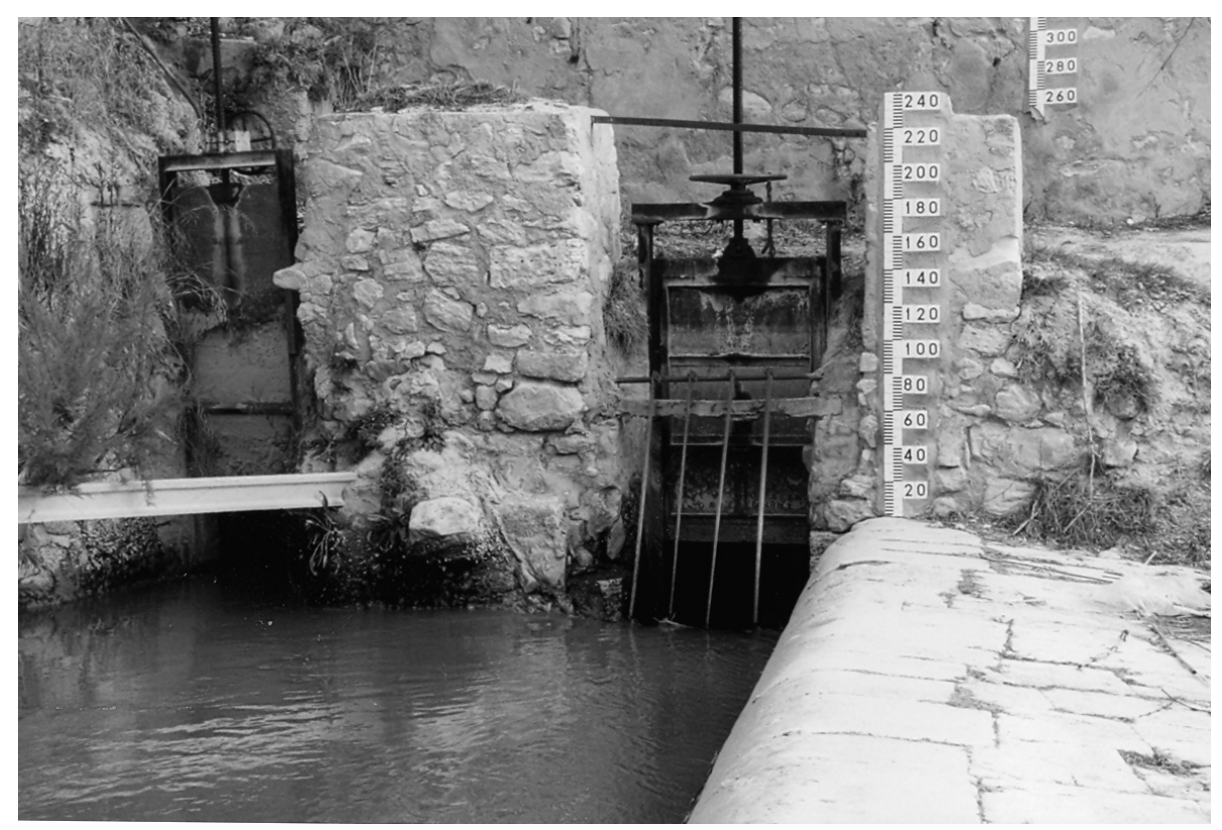

Compuertas del molino junto al azud de Alfaytamí (1990). 